\title{
Sensitivity of Dry Bean to Dimethenamid-p, Saflufenacil and Dimethenamid-p/Saflufenacil
}

\author{
Nader Soltani*, Christy Shropshire, Peter H. Sikkema \\ University of Guelph, Ridgetown Campus, Ridgetown, Canada \\ Email: soltanin@uoguelph.ca
}

Received 4 August 2014; revised 19 September 2014; accepted 21 October 2014

Copyright (C) 2014 by authors and Scientific Research Publishing Inc.

This work is licensed under the Creative Commons Attribution International License (CC BY). http://creativecommons.org/licenses/by/4.0/

(c) (i) Open Access

\section{Abstract}

There is limited information on the sensitivity of dry bean to dimethenamid-p, saflufenacil and a preformulated mixture of dimethenamid-p/saflufenacil. Field trials were conducted at Exeter and Ridgetown, ON, Canada in 2012 and 2013 to evaluate the tolerance of four market classes of dry bean to dimethenamid-p, saflufenacil and dimethenamid-p/saflufenacil applied preemergence (PRE) at the 1X and $2 X$ manufacturer's recommended rate in soybean. Dimethenamid-p, saflufenacil and dimethenamid-p/saflufenacil applied PRE caused 0\% - 2\%, 20\% - 31\% and 34\% - 45\% injury in dry bean, respectively. Dimethenamid-p (220 and $440 \mathrm{~g}^{\text {ai ha }} \mathrm{h}^{-1}$ ) caused no adverse effect on plant stand, shoot dry weight, height and yield of black, white, adzuki and kidney bean. Saflufenacil (25 and $50 \mathrm{~g}$ ai ha-1) or dimethenamid-p/saflufenacil ( 245 and $490 \mathrm{~g}^{-1}$ ha $^{-1}$ ) reduced plant stand $53 \%-70 \%$, shoot dry weight $61 \%-81 \%$, height $26 \%-48 \%$ and yield $40 \%-61 \%$ of black and white bean. However, saflufenacil applied alone or in combination with dimethenamid-p at the $1 \mathrm{X}$ or $2 \mathrm{X}$ rates caused no adverse effect on plant stand, shoot dry weight, height and yield of adzuki and kidney bean except with dimethenamid-p/saflufenacil at the $2 \mathrm{X}$ rate which reduced plant stand $38 \%$ in kidney bean, shoot dry weight $46 \%$ in adzuki bean and $42 \%$ in kidney bean, and yield $29 \%$ in kidney bean. Based on these results, saflufenacil and dimethenamid-p/saflufenacil applied PRE at the proposed rate of 25 and $245 \mathrm{~g}$ ai ha-1, respectively does have an adequate margin of crop safety for weed management in black and white bean. Further research is needed to ascertain the margin of crop safety in kidney and adzuki bean.

\section{Keywords}

Adzuki Bean, Black Bean, Kidney Bean, White Bean, Sensitivity, Tolerance

\footnotetext{
${ }^{*}$ Corresponding author.
} 


\section{Introduction}

Dry beans such as adzuki bean (Vigna angularis L.), black bean (Phaseolus vulgaris L.), kidney bean (Phaseolus vulgaris L.) and white bean (Phaseolus vulgaris L.) are important cash crops grown in southwestern Ontario. Short physical stature of these crops makes them not very competitive against weeds. Weed interference has been shown to reduce seed yield of dry bean as much as $70 \%$ [1]. Common annual weeds in dry bean production in Ontario include redroot pigweed (Amaranthus retroflexus L.), common lambsquarters (Chenopodium album L.), common ragweed (Ambrosia artemisiifolia L.), velvetleaf (Abutilon theophrasti Medicus), ladysthumb (Polygonum persicaria L.), eastern black nightshade (Solanum ptycanthum Dun.), and annual grasses such as Setaria, Digitaria, Echinochloa, and Panicum species [2].

Saflufenacil is a new herbicide developed by BASF for burndown and residual broadleaf weed control in corn, soybean, and other crops applied prior to crop emergence. Saflufenacil is a pyrimidinedione that inhibits the protoporphyrinogen-IX-oxidase (PPO) enzyme which is critical for chlorophyll synthesis. Saflufenacil is absorbed by both roots and foliage of plants. Saflufenacil is mainly translocated in the xylem and has limited mobility in the phloem. Plants susceptible to saflufenacil show injury symptoms within a few hours and die in 1 to 3 days after treatment (Anonymous 2008). Saflufenacil is applied at relatively low doses and has low environmental, toxicological and eco-toxicological impact with minimal residual carryover as the herbicide does not persist in the soil [3]. Saflufenacil effectively controls several broadleaf weeds in Ontario including redroot pigweed, common ragweed, common lambsquarters, velvetleaf, common cocklebur (Xanthium strumarium L.), giant ragweed (Ambrosia trifida L.) and common waterhemp (Amaranthus rudis Sauer) including triazine-, acetolactate synthase- and glyphosate-resistant biotypes [3] [4]. Saflufenacil is not very efficacious on annual grasses such as Setaria, Digitaria, Echinochloa, and Panicum species.

Dimethenamid-p is a chloroacetanilide herbicide that controls annual grasses such as green foxtail, yellow foxtail [Setaria glauca auct., non (L.) P. Beauv.], giant foxtail (Setaria faberi R.A.W. Herrm.), barnyardgrass [Echinochloa crus-galli (L.) Beauv.], witchgrass (Panicum capillare L.), fall panicum (Panicum dichotomiflorum Michx.), smooth crabgrass [Digitaria ischaemum (Schreb.) ex Muhl.], and large crabgrass [Digitaria sanguinalis (L.) Scop.] and some small-seeded broadleaf weeds such as redroot pigweed and eastern black nightshade including triazine- and acetolactate synthase-resistant biotypes [5]-[7].

Saflufenacil/dimethenamid-p is a new pre-packaged herbicide mixture available for use in soybean at a maximum dose of $245 \mathrm{~g}$ ai ha ${ }^{-1}$ (25:220 $\mathrm{g}$ ai ha ${ }^{-1}$ of saflufenacil:dimethenamid-p), in Ontario [2]. Saflufenacil used at a rate of 100 or $200 \mathrm{~g}$ ai ha ${ }^{-1}$ in Ontario has been shown to cause significant injury in some market classes of dry bean [8]. Dimethenamid-p and other chloroacetamide herbicides have been shown to have an adequate margin of crop safety in various market classes of dry beans [5] [9]-[11].

There is little information on the tolerance of black, white, adzuki and kidney beans to saflufenacil/dimethenamid-p herbicide mixture under Ontario environmental conditions. Saflufenacil at the proposed reduced rate of $25 \mathrm{~g}$ ai ha ${ }^{-1}$ in mixture with dimethenamid (220 $\left.\mathrm{g}_{\text {ai }} \mathrm{ha}^{-1}\right)$ may be an effective option for broad-spectrum control of annual grass and broadleaf weeds in dry beans.

The objective of this research was to evaluate the sensitivity of black, white, adzuki and kidney bean to saflufenacil/dimethenamid-p applied preemergence at the $1 \mathrm{X}$ and $2 \mathrm{X}$ manufacturer's recommended rates for soybean under Ontario environmental conditions.

\section{Materials and Methods}

Field trials were conducted at the Huron Research Station at Exeter, ON, Canada and at Ridgetown Campus of the University of Guelph at Ridgetown, ON, Canada in 2012 and 2013. The soil at Exeter was a Brookston clay loam (Orthic Humic Gleysol, mixed, mesic, and poorly drained) with 41\% sand, 35\% silt, 24\% clay, 3.2\% organic matter and pH of 7.9 in 2012 and 29\% sand, 44\% silt, 27\% clay, 3.6\% organic matter and pH of 7.7 in 2013. The soil at Ridgetown was a Watford (Grey to Brown Brunisolic, mixed, mesic, sandy, and imperfectly drained)-Brady (Gleyed Brunisolic Grey to Brown Luvisol, mixed, mesic, sandy, and imperfectly drained) sandy loam with 56\% sand, $27 \%$ silt, $17 \%$ clay, 5.4\% organic matter and pH of 6.7 in 2012 and 52\% sand, 28\% silt, 20\% clay, 5.9\% organic matter and $\mathrm{pH}$ of 6.4 in 2013. Seedbed preparation at all sites consisted of fall moldboard plowing followed by two passes with a field cultivator with rolling basket harrows in the spring.

The study was established as a split-plot in a randomized complete block design with four replications. Main plots consisted of untreated check, dimethenamid-p (220 g ai ha ${ }^{-1}$ ), dimethenamid-p (440 g ai ha ${ }^{-1}$ ), saflufenaci 
$\left(25 \mathrm{~g}_{\text {ai ha }}{ }^{-1}\right)$, saflufenacil $\left(50 \mathrm{~g}\right.$ ai ha $\left.{ }^{-1}\right)$, dimethenamid-p/saflufenacil $\left(220+25 \mathrm{~g}\right.$ ai ha $\left.{ }^{-1}\right)$, and dimethenamid$\mathrm{p} /$ saflufenacil $\left(440+50 \mathrm{~g} \mathrm{ai} \mathrm{ha}^{-1}\right)$ and sub-plots were market classes of dry bean which consisted of one row each of black bean ("Black Velvet”), white bean (“T9905”), adzuki bean ("Erimo”) and kidney bean ("Red Hawk") spaced $0.75 \mathrm{~m}$ apart. Plots were $3 \mathrm{~m}$ wide at both locations and $8 \mathrm{~m}$ long at Ridgetown and $10 \mathrm{~m}$ long at Exeter. Black, white, and adzuki bean were seeded at 250,000 seeds ha ${ }^{-1}$ and kidney bean was seeded at 200,000 seeds $\mathrm{ha}^{-1}$ using different seed disks at a depth of $5 \mathrm{~cm}$ in late May to early June.

Herbicide treatments were applied PRE to the soil surface one or two days after seeding. Herbicide treatments were applied with a $\mathrm{CO}_{2}$-pressurized backpack sprayer calibrated to deliver $200 \mathrm{~L} \cdot \mathrm{ha}^{-1}$ of spray solution at a pressure of 200/241 kPa using low drift nozzles (ULD120-02, Spraying Systems Co., P.O. Box 7900. Wheaton, IL 60188). The boom was $2.5 \mathrm{~m}$ wide with six nozzles spaced $0.5 \mathrm{~m}$ apart. All plots including the non-treated control were kept weed-free by inter-row cultivation and hand weeding as required.

Estimates of crop injury were evaluated 1, 2, and 4 weeks after emergence (WAE) using a scale of $0 \%$ to $100 \%$, where a rating of 0 was no plant injury and a rating of 100 was plant death. At 3 WAE, a $1 \mathrm{~m}$ section of row for each plot was hand harvested at the ground level, oven dried and the shoot dry weight was recorded. Plant stand was also counted at $3 \mathrm{WAE}$. At $6 \mathrm{WAE}$, ten plants from each plot were randomly selected and the height from the soil surface to the highest growing point was measured with a measuring stick and recorded as plant height. Yield was measured at maturity for each crop by combining the remaining $9 \mathrm{~m}$ from each plot at Exeter and $7 \mathrm{~m}$ from each plot at Ridgetown. Seed moisture content was adjusted to $18 \%$ for black, white and kidney bean and $13 \%$ for adzuki bean.

Data were analyzed as a 2-way factorial using PROC MIXED in SAS 9.2. Fixed effects included dry bean market class and herbicide treatment, as well as their interaction; random effects included year-location combinations (environment), interactions between environment and the fixed effects, and replicate nested within environment. Significance of fixed effects were tested using F-tests and random effects were tested using a Z-test of the variance estimate. The UNIVARIATE procedure was used to test data for normality and homogeneity of variance. To satisfy the assumptions of the variance analyses, injury 1, 2 and 4 WAE were arcsine square root transformed, percent plant stand, percent dry weight and percent yield were square root transformed and seed moisture content at harvest was log-transformed. For all injury ratings, the untreated check (assigned a value of zero) was excluded from the analysis. However, all values were compared independently to zero to evaluate treatment differences with the untreated check. Plant stand, dry weight, height and yield were converted to a percent of the untreated check for analysis. Treatment comparisons were made using Fisher's Protected LSD at a level of $\mathrm{P}<0.05$ and any data compared on the transformed scale were converted back to the original scale for presentation of results.

\section{Results and Discussion}

Statistical analysis indicated that for main effects of market class was significant for seed moisture content (Table 1). Also, herbicide treatment was significant for injury 1, 2 and 4 WAE, plant stand, dry weight, height, seed moisture content and yield (Table 1). Market class by treatment interaction was also significant for plant stand, dry weight, height and yield (Table 1).

\subsection{Crop Injury}

Injury symptoms caused by saflufenacil included leaf chlorosis followed by complete necrosis, decreased growth and reduced plant stand. Dimethenamid-p, saflufenacil and dimethenamid-p/saflufenacil applied PRE at the rates evaluated caused $0 \%-2 \%, 7 \%-31 \%$ and $13 \%-45 \%$ injury in dry beans, respectively (Table 1 ). In other studies saflufenacil applied PRE at 100 and $200 \mathrm{~g}_{\text {ai }} \mathrm{ha}^{-1}$ caused greater than $90 \%$ injury in cranberry bean, lima bean, snap bean, and white bean [8]. Adzuki bean was not as sensitive as cranberry, lima, snap, or white bean to saflufenacil but was injured $51 \%$ and $88 \%$ at 100 and $200 \mathrm{~g}$ ai ha ${ }^{-1}$, respectively [8]. The levels of injury observed in this study with saflufenacil or dimethanamid-p/saflufenacil was substantially higher than the level of injury observed with other PPO inhibitors such as fomesafen, flumioxazin and sulfentrazone in dry beans [12][16]. Sikkema et al. [13] found only 1\% or less injury in dry bean with fomesafen applied PRE. Sulfentrazone caused up to 30\% injury in black, brown, cranberry, kidney, otebo, pinto, white and yellow eye bean [12]. Flumioxazin caused as much as $34 \%$ injury in black, cranberry, kidney, and white bean [14]. 
Table 1. Main effects and interaction for percent visible injury, plant stand, dry weight, height, seed moisture content and seed yield of dry bean treated with dimethenamid-p and saflufenacil alone and in combination at Exeter and Ridgetown Ontario in 2012 and 2013. Plant stand, height, dry weight and yield are a percent of the untreated check. Means followed by the same letter within a column are not significantly different according to Fisher's Protected LSD at $\mathrm{P}<0.05$. Means for a main effect were separated only if there was no significant interaction involving that main effect ${ }^{\mathrm{a}}$.

\begin{tabular}{|c|c|c|c|c|c|c|c|c|c|c|c|c|c|}
\hline \multirow{3}{*}{ Main effects ${ }^{b}$} & & \multicolumn{6}{|c|}{ Dry Bean Injury } & \multirow{3}{*}{$\begin{array}{l}\text { Plant } \\
\text { Stand }\end{array}$} & \multirow{3}{*}{$\begin{array}{l}\text { Shoot } \\
\text { Dry } \\
\text { Weight }\end{array}$} & \multirow[b]{2}{*}{$\begin{array}{l}\text { Plant } \\
\text { Height }\end{array}$} & \multirow{2}{*}{\multicolumn{2}{|c|}{$\begin{array}{c}\text { Seed } \\
\text { Moisture } \\
\text { Content }\end{array}$}} & \multirow[b]{2}{*}{$\begin{array}{l}\text { Seed } \\
\text { Yield }\end{array}$} \\
\hline & & \multicolumn{2}{|c|}{$1 \mathrm{WAE}$} & \multicolumn{2}{|c|}{$2 \mathrm{WAE}$} & \multicolumn{2}{|c|}{$4 \mathrm{WAE}$} & & & & & & \\
\hline & & \multicolumn{6}{|c|}{$\%$} & & & \multicolumn{4}{|l|}{$\%$} \\
\hline Dry bean market class & & NS & & NS & & NS & & NS & NS & NS & ** & & NS \\
\hline Black & & 17 & & 18 & & 16 & & 77 & 71 & 91 & 18.4 & $\mathrm{~b}$ & 83 \\
\hline White & & 15 & & 20 & & 21 & & 71 & 65 & 86 & 21.0 & $\mathrm{~b}$ & 83 \\
\hline Adzuki & & 6 & & 8 & & 7 & & 92 & 86 & 99 & 13.8 & a & 114 \\
\hline Kidney & & 5 & & 7 & & 6 & & 89 & 84 & 96 & 19.8 & $\mathrm{~b}$ & 96 \\
\hline Herbicide treatment & $\begin{array}{c}\text { Rate } \\
\left.\text { (g ai ha }^{-1}\right)\end{array}$ & * & & $* *$ & & ** & & $* *$ & ** & $* *$ & $* *$ & & ** \\
\hline Untreated check & & 0 & $\mathrm{a}$ & 0 & $\mathrm{a}$ & 0 & $\mathrm{a}$ & 100 & 100 & 100 & 17.6 & $\mathrm{a}$ & 100 \\
\hline Dimethenamid-p & 220 & 1 & a & 0 & $\mathrm{a}$ & 0 & $\mathrm{a}$ & 109 & 106 & 102 & 17.5 & a & 106 \\
\hline Dimethenamid-p & 440 & 2 & $\mathrm{ab}$ & 1 & $\mathrm{ab}$ & 0 & $\mathrm{a}$ & 98 & 95 & 105 & 17.1 & a & 109 \\
\hline Saflufenacil & 25 & 7 & $a b$ & 11 & bc & 11 & $\mathrm{~b}$ & 81 & 74 & 97 & 17.8 & $a b$ & 104 \\
\hline Saflufenacil & 50 & 20 & bc & 30 & $\mathrm{~cd}$ & 31 & bc & 60 & 53 & 79 & 18.8 & bc & 75 \\
\hline Dimethenamid-p/saflufenacil & $220+25$ & 13 & $\mathrm{abc}$ & 18 & $\mathrm{~cd}$ & 14 & $\mathrm{~b}$ & 83 & 77 & 95 & 18.1 & $\mathrm{ab}$ & 99 \\
\hline Dimethenamid-p/saflufenacil & $440+50$ & 34 & c & 44 & d & 45 & c & 51 & 40 & 73 & 19.6 & c & 66 \\
\hline \multicolumn{14}{|l|}{ Interaction } \\
\hline $\mathrm{V} \times \mathrm{H}$ & & NS & & NS & & NS & & ** & ** & $* *$ & NS & & $* *$ \\
\hline
\end{tabular}

${ }^{\mathrm{a}}$ Abbreviations: WAE, weeks after emergence; $\mathrm{H}$, herbicide treatment; NS, not significant at $\mathrm{P}=0.05$ level; $\mathrm{V}$, dry bean market class. ${ }^{\mathrm{b}}$ Significance at $\mathrm{P}<$ 0.05 and $\mathrm{P}<0.01$ levels denoted by ${ }^{*}$ and ${ }^{* *}$, respectively.

\subsection{Plant Stand}

Dimethenamid-p at the $1 \mathrm{X}$ or $2 \mathrm{X}$ rate caused no adverse effect on plant stand of black, white, adzuki and kidney bean (Table 2). Saflufenacil applied alone or in combination with dimethenamid-p reduced plant stand as much as $53 \%$ in black bean, $70 \%$ in white bean and $38 \%$ in kidney bean but had no adverse effect on plant stand of adzuki bean (Table 2).

\subsection{Shoot Dry Weight}

Dimethenamid-p at $1 \mathrm{X}$ or $2 \mathrm{X}$ rate caused no adverse effect on shoot dry weight of black, white, adzuki and kidney bean (Table 2). Saflufenacil applied alone or in combination with dimethenamid-p reduced shoot dry weight as much as $63 \%$ in black bean and $81 \%$ in white bean but caused no adverse effect on shoot dry weight of adzuki or kidney bean except with dimethenamid-p/saflufenacil at $2 \mathrm{X}$ rate which reduced shoot dry weight $46 \%$ in adzuki bean and $42 \%$ in kidney bean (Table 2).

In other studies saflufenacil applied PRE at 100 and $200 \mathrm{~g}_{\text {ai ha }}{ }^{-1}$ reduced shoot dry weight $92 \%$ to $99 \%$ in adzuki, cranberry, lima, snap and white bean, averaged over application rates [8]. Shoot dry weight was reduced greater in cranberry, snap, white, and lima bean compared to adzuki bean [8]. Results in this study are consistent with other studies that have shown $0 \%$ to $40 \%$ shoot dry weight reductions with PPO herbicides such as fomesafen, flumioxazin and sulfentrazone [12]-[14].

\subsection{Plant Height}

Plant height is critical to dry bean producers as shorter plants at harvest can result in greater losses at the cutter 
Table 2. Plant stand, shoot dry weight, height and yield (both as a percent of the untreated check), for four dry bean market classes treated with dimethenamid-p and saflufenacil alone and in combination at Exeter and Ridgetown Ontario in 2012 and 2013. Means followed by the same letter within a column (a-c) or row (X-Z) are not significantly different according to Fisher's Protected LSD at $\mathrm{P}<0.05$.

\begin{tabular}{|c|c|c|c|c|c|c|c|c|c|c|c|c|c|}
\hline Herbicide Treatment & $\begin{array}{c}\text { Rate } \\
\left(\text { g ai ha }^{-1}\right)\end{array}$ & \multicolumn{3}{|c|}{ Black Bean } & \multicolumn{3}{|c|}{ White Bean } & \multicolumn{3}{|c|}{ Adzuki Bean } & \multicolumn{3}{|c|}{ Kidney Bean } \\
\hline Plant Stand & & & & & & & $\%$ & & & & & & \\
\hline Untreated check & & 100 & $\mathrm{ab}$ & $\mathrm{Z}$ & 100 & a & $\mathrm{Z}$ & 100 & a & $\mathrm{Z}$ & 100 & a & $\mathrm{Z}$ \\
\hline Dimethenamid-p & 220 & 123 & $\mathrm{a}$ & $\mathrm{Z}$ & 108 & a & $\mathrm{Z}$ & 100 & $\mathrm{a}$ & $\mathrm{Z}$ & 105 & a & $\mathrm{Z}$ \\
\hline Dimethenamid-p & 440 & 121 & a & $\mathrm{Z}$ & 98 & a & $\mathrm{YZ}$ & 94 & a & $\mathrm{YZ}$ & 81 & $a b$ & $\mathrm{Y}$ \\
\hline Saflufenacil & 25 & 59 & c & $\mathrm{Y}$ & 72 & a & $\mathrm{YZ}$ & 99 & a & Z & 99 & $\mathrm{ab}$ & Z \\
\hline Saflufenacil & 50 & 47 & c & $\mathrm{Y}$ & 33 & $\mathrm{~b}$ & $\mathrm{Y}$ & 90 & a & Z & 77 & $\mathrm{ab}$ & $\mathrm{Z}$ \\
\hline Dimethenamid-p/saflufenacil & $220+25$ & 65 & bc & $\mathrm{Y}$ & 77 & a & $\mathrm{YZ}$ & 91 & a & $\mathrm{YZ}$ & 102 & $\mathrm{a}$ & $\mathrm{Z}$ \\
\hline Dimethenamid-p/saflufenacil & $440+50$ & 47 & c & $\mathrm{YZ}$ & 30 & $\mathrm{~b}$ & $\mathrm{Y}$ & 69 & a & $\mathrm{Z}$ & 62 & $\mathrm{~b}$ & $\mathrm{Z}$ \\
\hline Shoot Dry Weight & & & & & & & $\%$ & & & & & & \\
\hline Untreated check & & 100 & $\mathrm{a}$ & Z & 100 & $a b$ & Z & 100 & a & Z & 100 & a & Z \\
\hline Dimethenamid-p & 220 & 117 & a & Z & 113 & a & Z & 98 & a & Z & 98 & a & Z \\
\hline Dimethenamid-p & 440 & 107 & a & Z & 104 & $\mathrm{ab}$ & Z & 87 & ab & Z & 84 & $\mathrm{ab}$ & Z \\
\hline Saflufenacil & 25 & 55 & b & $\mathrm{Y}$ & 59 & c & $\mathrm{Y}$ & 100 & a & Z & 86 & $\mathrm{ab}$ & $\mathrm{YZ}$ \\
\hline Saflufenacil & 50 & 39 & $\mathrm{~b}$ & $\mathrm{Y}$ & 26 & d & $\mathrm{Y}$ & 81 & ab & Z & 74 & $\mathrm{ab}$ & Z \\
\hline Dimethenamid-p/saflufenacil & $220+25$ & 62 & $\mathrm{~b}$ & $\mathrm{Z}$ & 71 & bc & Z & 87 & $\mathrm{ab}$ & Z & 90 & $\mathrm{ab}$ & Z \\
\hline Dimethenamid-p/saflufenacil & $440+50$ & 37 & $\mathrm{~b}$ & $\mathrm{YZ}$ & 19 & d & $\mathrm{Y}$ & 54 & $\mathrm{~b}$ & $\mathrm{Z}$ & 58 & $\mathrm{~b}$ & $\mathrm{Z}$ \\
\hline Height & & & & & & & $\%$ & & & & & & \\
\hline Untreated check & & 100 & a & $\mathrm{Z}$ & 100 & $\mathrm{ab}$ & $\mathrm{Z}$ & 100 & $\mathrm{ab}$ & $\mathrm{Z}$ & 100 & a & $\mathrm{Z}$ \\
\hline Dimethenamid-p & 220 & 100 & a & $\mathrm{Z}$ & 104 & $\mathrm{ab}$ & $\mathrm{Z}$ & 103 & $\mathrm{ab}$ & $\mathrm{Z}$ & 102 & a & $\mathrm{Z}$ \\
\hline Dimethenamid-p & 440 & 107 & $\mathrm{a}$ & $\mathrm{Z}$ & 108 & a & Z & 103 & ab & Z & 102 & $\mathrm{a}$ & $\mathrm{Z}$ \\
\hline Saflufenacil & 25 & 93 & a & $\mathrm{Z}$ & 91 & $\mathrm{ab}$ & $\mathrm{Z}$ & 105 & a & $\mathrm{Z}$ & 98 & a & $\mathrm{Z}$ \\
\hline Saflufenacil & 50 & 74 & $\mathrm{~b}$ & $\mathrm{XY}$ & 59 & c & $\mathrm{X}$ & 94 & $\mathrm{ab}$ & $\mathrm{Z}$ & 90 & a & $\mathrm{YZ}$ \\
\hline Dimethenamid-p/saflufenacil & $220+25$ & 95 & a & Z & 87 & $\mathrm{~b}$ & $\mathrm{Z}$ & 102 & $\mathrm{ab}$ & Z & 95 & a & Z \\
\hline Dimethenamid-p/saflufenacil & $440+50$ & 69 & $\mathrm{~b}$ & $\mathrm{XY}$ & 52 & c & $\mathrm{X}$ & 86 & $\mathrm{~b}$ & $\mathrm{Z}$ & 85 & a & $\mathrm{YZ}$ \\
\hline Seed Yield & & & & & & & $\%$ & & & & & & \\
\hline Untreated check & & 100 & a & Z & 100 & a & $\mathrm{Z}$ & 100 & $\mathrm{a}$ & $\mathrm{Z}$ & 100 & abc & $\mathrm{Z}$ \\
\hline Dimethenamid-p & 220 & 99 & a & Z & 115 & a & $\mathrm{Z}$ & 105 & a & Z & 106 & $\mathrm{ab}$ & $\mathrm{Z}$ \\
\hline Dimethenamid-p & 440 & 101 & a & Z & 113 & a & $\mathrm{Z}$ & 107 & a & Z & 115 & a & Z \\
\hline Saflufenacil & 25 & 88 & $a b$ & $\mathrm{Z}$ & 99 & a & $\mathrm{Z}$ & 124 & $\mathrm{a}$ & $\mathrm{Z}$ & 106 & $a b$ & $\mathrm{Z}$ \\
\hline Saflufenacil & 50 & 60 & bc & $\mathrm{XY}$ & 46 & $\mathrm{~b}$ & $\mathrm{X}$ & 129 & a & $\mathrm{Z}$ & 78 & bc & $\mathrm{Y}$ \\
\hline Dimethenamid-p/saflufenacil & $220+25$ & 89 & $a b$ & $\mathrm{Z}$ & 90 & a & $\mathrm{Z}$ & 120 & a & Z & 99 & abc & Z \\
\hline Dimethenamid-p/saflufenacil & $440+50$ & 53 & c & $\mathrm{XY}$ & 39 & $\mathrm{~b}$ & $\mathrm{X}$ & 114 & a & Z & 71 & c & $\mathrm{Y}$ \\
\hline
\end{tabular}

bar of the combine and reduce seed yield. Dimethenamid-p at $1 \mathrm{X}$ or $2 \mathrm{X}$ rate caused no adverse effect on height of black, white, adzuki and kidney bean (Table 2). Saflufenacil applied alone or in combination with dimethenamid-p at $1 \mathrm{X}$ rate had no adverse effect on plant height but at $2 \mathrm{X}$ rate reduced plant height as much as $31 \%$ in black bean and $48 \%$ in white bean (Table 2). Saflufenacil applied alone or in combination with dimethenamid-p 
at $1 \mathrm{X}$ or $2 \mathrm{X}$ rate caused no adverse effect on height of adzuki or kidney bean (Table 2).

In other studies saflufenacil applied PRE reduced plant height $>65 \%$ at $100 \mathrm{~g}$ ai ha ${ }^{-1}$ and $63 \%$ to $93 \%$ at 200 $\mathrm{g}$ ai ha ${ }^{-1}$ in cranberry, lima, snap, and white bean and 25\% in adzuki bean [8]. Plant height reductions in this study are consistent with what has been reported with other PPO-inhibiting herbicides such as fomesafen, flumioxazin and sulfentrazone that have reduced dry bean height $0 \%$ to $47 \%$ [12]-[16].

\subsection{Yield}

Dimethenamid-p at $1 \mathrm{X}$ or $2 \mathrm{X}$ rate caused no adverse effect on seed yield of black, white, adzuki and kidney bean (Table 2). Saflufenacil applied alone or in combination with dimetheanamid-p at $1 \mathrm{X}$ rates did not cause any significant seed yield reduction in black or white bean but at $2 \mathrm{X}$ rates reduced seed yield $40 \%-47 \%$ in black bean and 54\% - 61\% in white bean (Table 2). Saflufenacil applied alone or in combination with dimethenamid-p at $1 \mathrm{X}$ or $2 \mathrm{X}$ rates caused no adverse effect on seed yield of adzuki or kidney bean (Table 2).

In other studies saflufenacil applied PRE at 100 and $200 \mathrm{~g}$ ai ha $^{-1}$ reduced seed yield 56\% to $99 \%$ in adzuki, cranberry, lima, snap and white bean [8]. Studies with other PPO inhibitors have shown 47\%, 44\%, 26\% and 52\% yield reduction with sulfentrazone in black, cranberry, otebo and white bean, respectively [12]. Flumioxazin reduced seed yield $20 \%$ to $30 \%$ in black and white bean [14]. However, other PPO inhibitors such as fomesafen have been shown to have little effect on the seed yield of dry bean [13] [16].

\section{Conclusions}

Based on these results, saflufenacil and dimethenamid-p/saflufenacil applied PRE at the proposed rate of $25 \mathrm{~g}$ ai $\mathrm{ha}^{-1}$ can be safely used for weed management in adzuki bean. There is also potential for use of saflufenacil and dimethenamid-p/saflufenacil applied PRE at the $25 \mathrm{~g}_{\text {ai }} \mathrm{ha}^{-1}$ in kidney bean. However, saflufenacil and dimethenamid-p/saflufenacil applied PRE at the proposed rates cause substantial injury and a reduction in plant stand, height, shoot dry weight and seed yield in black and white bean. Results showed that black and white bean are the most sensitive to saflufenacil and dimethenamid-p/saflufenacil followed by kidney bean and then adzuki bean.

Dimethenamid-p/saflufenacil with its novel mode of action would be a desirable compliment to the current weed management programs for PRE control of troublesome broadleaf weeds in adzuki bean. More research is needed to evaluate other market classes of dry bean to saflufenacil and dimethenamid-p/saflufenacil.

\section{Acknowledgements}

The authors would like to acknowledge Todd Cowan for his expertise and technical assistance in these studies. Funding for this project was provided in part by BASF and the GF2 program of the Agricultural Adaptation Council.

\section{References}

[1] Malik, V.S., Swanton, C.J. and Michaels, T.E. (1993) Interaction of White Bean (Phaselous vulgaris L.) Cultivars, Row Spacing, and Seeding Density with Annual Weeds. Weed Science, 41, 62-68.

[2] Ontario Ministry of Agriculture, Food and Rural Affairs (2014) Guide to Weed Control. Publication 75, Toronto.

[3] Anonymous (2008) Kixor ${ }^{\circledR}$ Worldwide Technical Brochure. Research Triangle Park, NC, BASF Corporation, 18 p.

[4] Liebl, R.A., Walter, H., Bowe, S.J., Holt, T.J. and Westberg, D.E. (2008) BAS 800H: A New Herbicide for Preplant Burndown and Preemergence Dicot Weed Control. WSSA Abstract, 48, 120.

[5] Arnold, N.R., Murray, W.M., Gregory, J.E. and Smeal, D. (1993) Weed Control in Pinto Beans (Phaseolus vulgaris) with Imazethapyr Combinations. Weed Technology, 7, 361-364.

[6] Bauer, T.A., Renner, K.A., Penner, D. and Kelly, J.D. (1995) Pinto Bean (Phaseolus vulgaris) Varietal Tolerance to Imazethapyr. Weed Science, 43, 417-424.

[7] Senseman, S.A. (2007) Herbicide Handbook. 9th Edition, Weed Science Society of America, Champaign, 458 p.

[8] Soltani, N., Shropshire, C. and Sikkema, P.H. (2010) Sensitivity of Leguminous Crops to Saflufenacil. Weed Technology, 24, 143-146. http://dx.doi.org/10.1614/WT-09-029.1

[9] Soltani, N., Shropshire, C., Cowan, T. and Sikkema, P.H. (2004) Tolerance of Black Beans (Phaseolus vulgaris) to 
Soil Applications of S-Metolachlor and Imazethapyr. Weed Technology, 18, 166-173. http://dx.doi.org/10.1614/WT-03-044R

[10] Soltani, N., Robinson, D.E., Shropshire, C. and Sikkema, P.H. (2006) Otebo Bean (Phaseolus vulgaris) Sensitivity to Pre-Emergence Herbicides. Crop Protection, 25, 476-479. http://dx.doi.org/10.1016/j.cropro.2005.08.002

[11] Soltani, N. and Sikkema, P.H. (2005) White Bean (Phaseolus vulgaris) Tolerance to Preplant-Incorporated Herbicides. Weed Biology and Management, 5, 35-38. http://dx.doi.org/10.1111/j.1445-6664.2005.00153.x

[12] Hekmat, S., Shropshire, C., Soltani, N. and Sikkema, P.H. (2007) Response of Dry Bean to Sulfentrazone. Crop Protection, 26, 525-529. http://dx.doi.org/10.1016/j.cropro.2006.05.002

[13] Sikkema, P.H., Shropshire, C. and Soltani, N. (2009) Responses of Dry Bean to Pre-Plant Incorporated and Pre-Emergence Applications of S-Metolachlor and Fomesafen. Crop Protection, 28, 744-748. http://dx.doi.org/10.1016/j.cropro.2009.05.011

[14] Soltani, N., Bowley, S. and Sikkema, P.H. (2005) Responses of Dry Beans (Phaseolus vulgaris) to Flumioxazin. Weed Technology, 19, 351-358. http://dx.doi.org/10.1614/WT-04-146R1

[15] VanGessel, J.M., Monks, W.D. and Quintin, R.J. (2000) Herbicides for Potential Use in Lima Bean (Phaseolus lunatus) Production. Weed Technology, 14, 279-286. http://dx.doi.org/10.1614/0890-037X(2000)014[0279:HFPUIL]2.0.CO;2

[16] Wilson, R.G. (2005) Responses of Dry Bean and Weeds to Fomesafen and Fomesafen Tankmixtures. Weed Technology, 19, 201-206. http://dx.doi.org/10.1614/WT-04-166R 
Scientific Research Publishing (SCIRP) is one of the largest Open Access journal publishers. It is currently publishing more than 200 open access, online, peer-reviewed journals covering a wide range of academic disciplines. SCIRP serves the worldwide academic communities and contributes to the progress and application of science with its publication.

Other selected journals from SCIRP are listed as below. Submit your manuscript to us via either submit@scirp.org or Online Submission Portal.
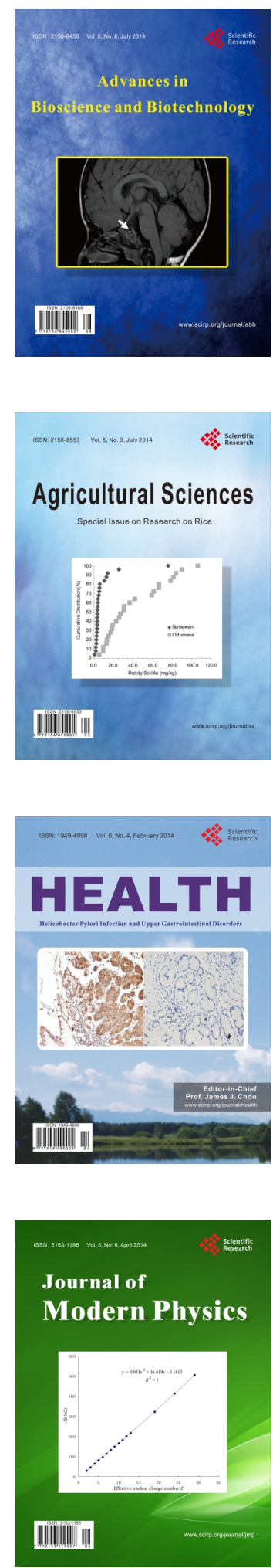
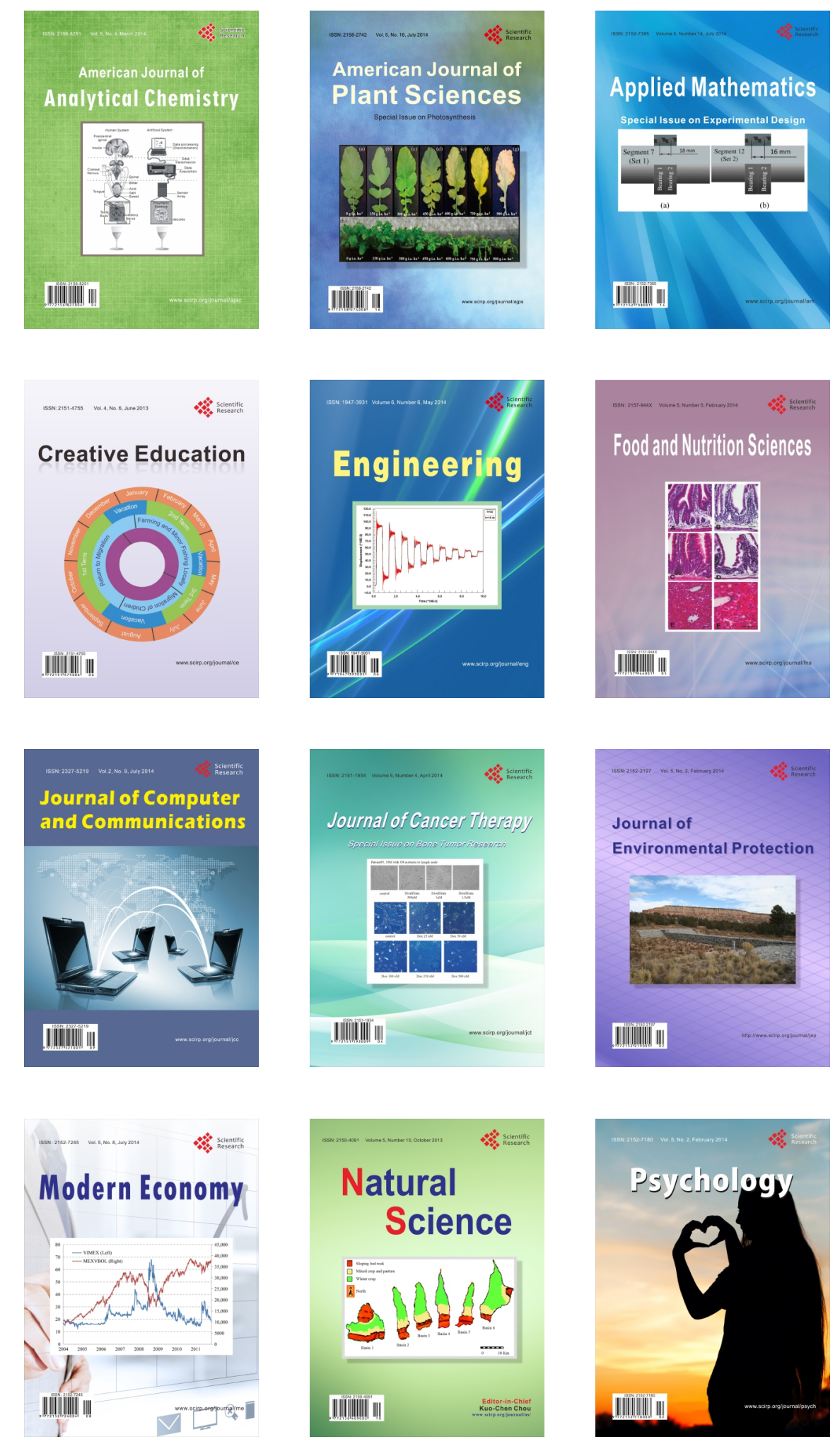